Article

\title{
Available Nitrogen and Responses to Nitrogen Fertilizer in Brazilian Eucalypt Plantations on Soils of Contrasting Texture
}

\author{
Ana Paula Pulito ${ }^{1}$, José Leonardo de Moraes Gonçalves ${ }^{2, *}$, Philip J. Smethurst ${ }^{3}$, \\ José Carlos Arthur Junior ${ }^{4}$, Clayton Alcarde Alvares ${ }^{5}$, José Henrique Tertulino Rocha ${ }^{2}$, \\ Ayeska Hübner ${ }^{2}$, Luiz Fabiano de Moraes ${ }^{6}$, Aline Cristina Miranda ${ }^{7}$, Marcos Yassuo Kamogawa ${ }^{8}$, \\ José Luiz Gava ${ }^{6}$, Raul Chaves ${ }^{9}$ and Claudio Roberto Silva ${ }^{1}$
}

1 Fibria S.A., Aracruz CEP: 29197-900, Brazil;

E-Mails: ana.pulito@fibria.com.br (A.P.P.); claudio.silva@fibria.com.br (C.R.S.)

2 Department of Forest Science, Luiz de Queiroz College of Agriculture (ESALQ), University of São Paulo (USP), Piracicaba CEP:13418-900, Brazil; E-Mails: jlmgonca@usp.br (J.L.M.G.); rocha.jht@gmail.com (J.H.T.R.); ayeskahubner@yahoo.com.br (A.H.)

3 CSIRO, Private Bag 12, Hobart TAS 7001, Australia; E-Mail: philip.smethurst@csiro.au

4 Forest Science and Research Institute (IPEF), Piracicaba, CEP: 13400-970, Brazil;

E-Mail: arthur@ipef.br

5 Department of Forestry and Environmental Resources, North Carolina State University, Raleigh, NC 27695, USA; E-Mail: calcard@ncsu.edu

6 Suzano, Itapetininga CEP: 18207-780, Brazil; E-Mails: 1uizmoraes@suzano.com.br (L.F.M.); jgava@suzano.com.br (J.L.G.)

7 Department of Forest Science, “Julio de Mesquita Filho" Universidade Estadual Paulista, Botucatu CEP: 18603-970, Brazil; E-Mail: miranda.acf@gmail.com

8 Mathematics, Statistics and Chemistry Department, Luiz de Queiroz College of Agriculture (ESALQ), University of São Paulo (USP), Piracicaba CEP:13418-900, Brazil;

E-Mail: kamogawa@usp.br

9 Duratex, Agudos CEP: 17120-000, Brazil; E-Mail: raul.chaves@duratex.com.br

* Author to whom correspondence should be addressed; E-Mail: jlmgonca@usp.br; Tel.: +55-2105-8644.

Academic Editor: Reynaldo Campos Santana

Received: 22 December 2014 / Accepted: 19 March 2015 / Published: 2 April 2015

Abstract: Eucalyptus plantations have seldom responded to $\mathrm{N}$ fertilization in tropical and subtropical regions of Brazil. This implies that rates of $\mathrm{N}$ mineralization have been adequate 
to supply tree needs. However, subsequent crop rotations with low $\mathrm{N}$ fertilization may result in declining concentrations of organic and potentially mineralizable $\mathrm{N}\left(\mathrm{N}_{0}\right)$, and consequent loss of wood productivity. This study investigated (a) in situ $\mathrm{N}$ mineralization and $\mathrm{N}_{0}$ in soils of eucalypt plantations in São Paulo state, Brazil; (b) tree growth responses to $\mathrm{N}$ fertilizer applied 6-18 months after planting; and (c) the relationships between $\mathrm{N}_{0}$, other soil attributes and tree growth. We established eleven $\mathrm{N}$ fertilizer trials (maximum $240 \mathrm{~kg} \mathrm{ha}^{-1}$ of $\mathrm{N}$ ) in E. grandis and E. grandis $\mathrm{x}$ urophylla plantations. The soil types at most sites were Oxisols and Quartzipsamments, with a range of organic matter (18 to $55 \mathrm{~g} \mathrm{~kg}^{-1}$ ) and clay contents ( $8 \%$ to $67 \%$ ) in the $0-20 \mathrm{~cm}$ layer. Concentrations of $\mathrm{N}_{0}$ were measured using anaerobic incubation on soil samples collected every three months (different seasons). The samples collected in spring and summer had $\mathrm{N}_{0} 140-400 \mathrm{~kg} \mathrm{ha}^{-1}(10 \%-19 \%$ total soil $\mathrm{N})$, which were best correlated with soil texture and organic matter content. Rates of in situ net $\mathrm{N}$ mineralization (0-20 cm) ranged from 100 to $200 \mathrm{~kg} \mathrm{ha}^{-1}$ year $^{-1}$ and were not correlated with clay, total $\mathrm{N}$, or $\mathrm{N}_{0}$. These high $\mathrm{N}$ mineralization rates resulted in a low response to $\mathrm{N}$ fertilizer application during the early ages of stand growth, which were highest on sandy soils. At the end of the crop rotation, the response to $\mathrm{N}$ fertilizer was negligible and non-significant at all sites.

Keywords: forest; productivity; potentially mineralizable $\mathrm{N}$; sustainability; fertilizer application; nutrition

\section{Introduction}

Establishment of a forest plantation using the Eucalyptus genus for pulp and paper production and other products is justified by their high productivity across different soils and climates. However, sustainable wood production might be compromised in the short- or long-term when plantations are established on soils of low fertility, such as Oxisols and Quartzipsamments [1,2]. Productive plantations with high capacity for nutrient extraction can greatly impact $\mathrm{N}$ pools in the soil. Adequate management practices, including fertilizer application, are required to sustain tree growth rates and ensure soil quality over successive rotations [3].

Although trees require large amounts of $\mathrm{N}$, some researchers found that eucalypts did not respond to $\mathrm{N}$ fertilizer application under tropical and subtropical climate conditions $[1,4,5]$. Commonly, $\mathrm{N}$ fertilizer application enhances the early growth of a eucalypt stand, but the response is not continued through the entire rotation [3-5]. The lack of response possibly occurs due to significant mineralization rates of organic $\mathrm{N}[3,6]$ and to atmospheric $\mathrm{N}$ deposition [7-10]. Mineralization of organic $\mathrm{N}$ is the main natural $\mathrm{N}$ source for plantations and appears to be sufficient to meet tree demand [3,11], which in southeast Brazil ranges from 20 to $50 \mathrm{~kg} \mathrm{ha}^{-1}$ year $^{-1}[3,6]$. However, intensively managed eucalypt plantations are expected to respond to $\mathrm{N}$ fertilizer application following several crop rotations because of high $\mathrm{N}$ outputs via harvesting [3,6,12], low $\mathrm{N}$ fertilizer rates applied [1,13], and depletion of organic $\mathrm{N}$ pools in soil [3]. Some studies carried out at sites with low soil organic matter (SOM) and N status showed that eucalypt 
stands might respond to $\mathrm{N}$ application under this condition [14,15]. Hence, the need for $\mathrm{N}$ fertilization in Brazilian plantations should be examined each rotation across a range of soil types.

The complexity of determining $\mathrm{N}$ fertilizer recommendations is attributed to the difficulty in accurately predicting the supply of available $\mathrm{N}$ ( $\mathrm{N}$ mineralization). Gonçalves et al. [2] described a recommendation index for $\mathrm{N}$ fertilizer application to eucalypt plantations in Brazil based on SOM content. Although SOM is the main source of N, such an indicator does not consider the effect of SOM quality, climate and forest management [16,17].

The definition of a useful index of $\mathrm{N}$ availability is one that is practical, and chemical analyses can be faster than biological assays [18,19]. Several laboratory methods have been proposed to estimate potentially mineralizable $\mathrm{N}\left(\mathrm{N}_{0}\right)$ in soils, and the anaerobic incubation method appears promising [11,20,21].

To better understand the interactions of $\mathrm{N}$ supply and tree growth at this stage of eucalypt plantation development in southeast Brazil,, this study investigated (a) in situ $\mathrm{N}$ mineralization and $\mathrm{N}_{0}$ in soils of eucalypt plantations in São Paulo state, Brazil, (b) tree growth responses to $\mathrm{N}$ fertilizer applied 6-18 months after planting, and (c) the relationships between $\mathrm{N}_{0}$, other soil attributes and tree growth.

\section{Material and Methods}

\subsection{Site Description}

We selected eleven Eucalyptus grandis and Eucalyptus grandis $\times$ urophylla sites in São Paulo state, Brazil, ranging from 1 to 11.4 years old. The sites belong to industrial companies and to the Itatinga Experimental Station of Forest Sciences, University of São Paulo and are representative of the majority of soils, climates and plantation management in this state (Figure 1). The climate is Cwa, according to Köppen classification at Altinópolis site; Cfa at Agudos, Angatuba, Capão Bonito, São Miguel Arcanjo and Votorantim sites; and $\mathrm{Cfb}$ at Botucatu, Itatinga and Paraibuna sites [22]. Cwa is a humid subtropical climate with a dry winter and a hot summer. Cfa is a humid subtropical climate without a dry season and with a hot summer. $\mathrm{Cfb}$ is a humid subtropical climate without a dry season and with a temperate summer. $\mathrm{C}$ climate types have an average annual temperature below $18^{\circ} \mathrm{C}$. $\mathrm{Cw}$ climates have rainfall of the driest month (RDRY) more than $40 \mathrm{~mm}$, while the Cf climates have RDRY less than $40 \mathrm{~mm}$. Average annual rainfall at the studied sites ranges from 1170 to $1517 \mathrm{~mm}$ (Table 1). Soils in the municipalities of Itatinga, São Miguel Arcanjo and Paraibuna are Typic Hapludox (Red-Yellow Latosol); at Altinópolis, Angatuba and Botucatu, Typic Quartzipsamment (Quartzarenic Neosol); at Agudos and Capão Bonito 2, Typic Hapludox (Red Latosol); at Capão Bonito 1, Typic Hapludox (Yellow Latosol); at Votorantim, Typic Paleudult (Red-Yellow Argisol); and at Capão Bonito 3, Typic Dystropept (Dystrophic Cambisol) [23]. These are the main soils used in forest plantations in São Paulo State [2]. Further soil details of Itatinga and Capão Bonito can be found in Gonçalves et al. [24] and Alvares et al. [25], respectively. The contents of SOM ranged from 18 to $55 \mathrm{~g} \mathrm{~kg}^{-1}$ and clay contents from $8 \%$ to $68 \%$ in the $0-20 \mathrm{~cm}$ layer (Table 2). They are also quite acidic with $\mathrm{pH} 3.9-4.9$. 


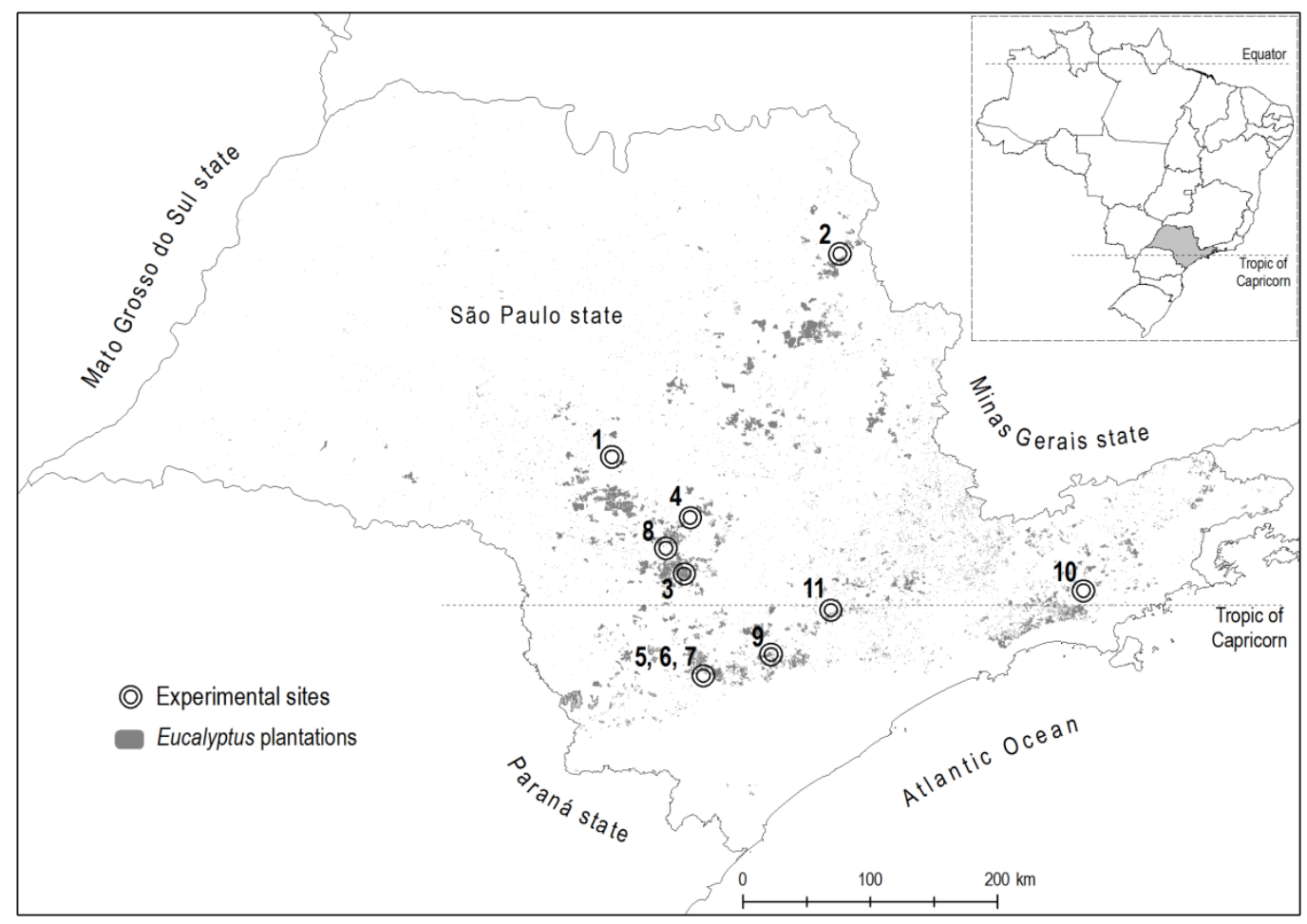

Figure 1. Map of São Paulo state showing locations of the experimental sites: 1-Agudos; 2-Altinópilis; 3-Angatuba; 4-Botucatu; 5, 6, 7-Capão Bonito; 8-Itatinga; 9-São Miguel Arcanjo; 10—Paraibuna; and 11-Votorantim.

At each site, we used a randomized block experimental design with three replicates. Measured plots were $10 \mathrm{~m}$ by $10 \mathrm{~m}$, with 36 trees per plot, surrounded by a two-tree border. The treatments were: (i) control (low $\mathrm{N}$ dose of fertilizer application, sufficient to provide good establishment of plants; c. $15 \mathrm{~kg} \mathrm{ha}^{-1}$ ); (ii) usual dose ( $\mathrm{N}$ dose used by the companies; $c .100 \mathrm{~kg} \mathrm{ha}^{-1}$ ); and (iii) increased dose ( $100 \%$ higher than commercial doses; c. $200 \mathrm{~kg} \mathrm{ha}^{-1}$ ). The $\mathrm{N}$ fertilizer application schedule was $25 \%$ of total dose at planting, and the rest applied equitably at 6,12 and 18 months after planting. The fertilizer application after planting was placed in a continuous line under canopy projection. Additional to $\mathrm{N}$ fertilization, all treatments received $30 \mathrm{~kg} \mathrm{ha}^{-1}$ of $\mathrm{P}, 130 \mathrm{~kg} \mathrm{ha}^{-1}$ of $\mathrm{K}, 230 \mathrm{~kg} \mathrm{ha}^{-1}$ of Ca, $100 \mathrm{~kg} \mathrm{ha}^{-1}$ of $\mathrm{Mg}, 3 \mathrm{~kg} \mathrm{ha}^{-1}$ of B, $60 \mathrm{~kg} \mathrm{ha}^{-1}$ of S, $1.5 \mathrm{~kg} \mathrm{ha}^{-1}$ of $\mathrm{Zn}$ and $0.5 \mathrm{~kg} \mathrm{ha}^{-1}$ of Cu. Calcium and $\mathrm{Mg}$ were supplied through lime application. Throughout the experiment, the stands were kept free of weed competition by herbicide application. 
Table 1. Latitude (Lat), longitude (Long), altitude (Alt), mean annual temperature (T), mean annual pluviometric precipitation (PP), topography, planted genotype, tree spacing and planting date of each experiment.

\begin{tabular}{|c|c|c|c|c|c|c|c|c|c|c|c|}
\hline \multirow{2}{*}{ Municipality } & \multirow{2}{*}{ Site Code } & \multirow{2}{*}{ Lat } & \multirow{2}{*}{ Long } & \multirow{2}{*}{ Alt } & \multirow{2}{*}{$\mathbf{T}^{3}$} & \multirow{2}{*}{ PP } & \multicolumn{2}{|r|}{ Geology 4} & \multirow{2}{*}{ Genotype } & \multirow{2}{*}{ Tree Spacing } & \multirow{2}{*}{ Planting } \\
\hline & & & & & & & Formation or Group & Lithotype & & & \\
\hline & & $\mathrm{S}$ & $\mathrm{W}$ & $\mathrm{m}$ & ${ }^{\circ} \mathrm{C}$ & $\mathrm{mm}$ & & & & $\mathrm{m}$ & \\
\hline Agudos & AGU & $22^{\circ} 28^{\prime}$ & $48^{\circ} 59^{\prime}$ & 580 & 20.6 & 1170 & Marília & $\begin{array}{c}\text { Sandstone, sandy argillite and } \\
\text { limestone }\end{array}$ & E.grandis ${ }^{1}$ & $3.0 \times 2.0$ & Aug-2005 \\
\hline Altinópolis & ALT & $21^{\circ} 01^{\prime}$ & $47^{\circ} 22^{\prime}$ & 889 & 19.4 & 1517 & Botucatu & Quartz-sandstone & E.grandis $\times$ urophylla ${ }^{2}$ & $3.0 \times 2.5$ & May-2002 \\
\hline Angatuba & ANG & $23^{\circ} 17^{\prime}$ & $48^{\circ} 28^{\prime}$ & 649 & 19.7 & 1262 & Pirambóia & $\begin{array}{l}\text { Shale, thin sandstone and } \\
\text { silty-clayey sandstone }\end{array}$ & E.grandis $\times$ urophylla ${ }^{2}$ & $3.0 \times 2.0$ & Apr-2006 \\
\hline Botucatu & BOT & $22^{\circ} 53^{\prime}$ & $48^{\circ} 26^{\prime}$ & 804 & 19.1 & 1302 & Marília & $\begin{array}{l}\text { Sandstone, sandy argillite and } \\
\text { limestone }\end{array}$ & E.grandis ${ }^{1}$ & $3.0 \times 2.0$ & Nov-2005 \\
\hline Capão Bonito 1 & CB1 & $24^{\circ} 00^{\prime}$ & $48^{\circ} 20^{\prime}$ & 705 & 18.9 & 1210 & & & E.grandis $\times$ urophylla ${ }^{2}$ & $3.0 \times 3.0$ & Jun-1999 \\
\hline Capão Bonito 2 & $\mathrm{CB} 2$ & $24^{\circ} 00^{\prime}$ & $48^{\circ} 20^{\prime}$ & 705 & 18.9 & 1210 & Itararé & Sandstone, diamictite and shale & E.grandis $\times$ urophylla ${ }^{2}$ & $3.0 \times 2.0$ & Feb-2007 \\
\hline Capão Bonito 3 & $\mathrm{CB} 3$ & $24^{\circ} 00^{\prime}$ & $48^{\circ} 20^{\prime}$ & 705 & 18.9 & 1210 & & & E.grandis $\times$ urophylla ${ }^{2}$ & $3.0 \times 2.0$ & Dec-2006 \\
\hline Itatinga & ITA & $23^{\circ} 06^{\prime}$ & $48^{\circ} 36^{\prime}$ & 845 & 18.8 & 1308 & Marília & $\begin{array}{c}\text { Sandstone, sandy argillite and } \\
\text { limestone }\end{array}$ & E.grandis ${ }^{1}$ & $3.0 \times 2.0$ & Apr-2002 \\
\hline São M. Arcanjo & SMA & $23^{\circ} 51^{\prime}$ & $47^{\circ} 51^{\prime}$ & 715 & 18.9 & 1174 & Itararé & Sandstone, diamictite and shale & E.grandis $\times$ urophylla ${ }^{2}$ & $3.0 \times 2.0$ & Aug-2006 \\
\hline Paraibuna & PAR & $23^{\circ} 23^{\prime}$ & $45^{\circ} 39^{\prime}$ & 634 & 19.2 & 1249 & Natividade da Serra & $\begin{array}{c}\text { Monzogranite, biotite } \\
\text { and granite }\end{array}$ & E.grandis ${ }^{1}$ & $3.0 \times 2.5$ & Mar-1997 \\
\hline Votorantim & VOT & $23^{\circ} 32^{\prime}$ & $47^{\circ} 26^{\prime}$ & 570 & 19.8 & 1287 & Granite Sorocaba & $\begin{array}{c}\text { Granite, Granodiorite, } \\
\text { monzogranite and syenogranite }\end{array}$ & E.grandis $\times$ urophylla ${ }^{2}$ & $3.0 \times 2.0$ & Oct-2006 \\
\hline
\end{tabular}

${ }^{1}$ Seedling plantations; ${ }^{2}$ Clonal plantations; ${ }^{3}$ Alvares et al. [26]; ${ }^{4}$ IPT [27]. 
Table 2. Soil physical and chemical attributes (0-20 cm layer) at the eleven sites.

\begin{tabular}{|c|c|c|c|c|c|c|c|c|c|c|c|}
\hline \multirow{2}{*}{ Site } & \multirow{2}{*}{ Clay ${ }^{1}$} & \multirow{2}{*}{ Silt $^{1}$} & \multicolumn{2}{|c|}{ Sand $^{1}$} & \multirow{2}{*}{$\mathbf{O M}^{2}$} & \multirow{2}{*}{$\mathbf{p H}^{3}$} & \multirow{2}{*}{ P-resin 4} & \multicolumn{4}{|c|}{ Cation Exchange $^{4}$} \\
\hline & & & Coarse & Fine & & & & $\mathbf{K}$ & $\mathbf{C a}$ & Mg & Al \\
\hline & & \multicolumn{2}{|c|}{$\%$} & & \multicolumn{2}{|l|}{$\mathrm{g} \mathrm{kg}^{-1}$} & \multicolumn{2}{|l|}{$\mathrm{mg} \mathrm{kg}^{-1}$} & \multicolumn{2}{|c|}{ mmolc $_{\mathbf{c}} \mathbf{k g}^{-1}$} & \\
\hline AGU & 16.7 & 2.7 & 30.7 & 49.9 & 15 & 3.9 & 2.3 & 0.6 & 1.0 & 0.6 & 8.3 \\
\hline ALT & 6.7 & 1.3 & 38.7 & 53.3 & 13 & 4.3 & 4.4 & 0.8 & 4.8 & 1.9 & 3.7 \\
\hline ANG & 10.0 & 1.0 & 29.3 & 59.7 & 16 & 4.0 & 8.5 & 0.5 & 5.3 & 1.5 & 7.6 \\
\hline BOT & 10.0 & 3.0 & 32.0 & 55.0 & 11 & 4.0 & 4.8 & 0.3 & 3.0 & 3.7 & 4.1 \\
\hline CB1 & 47.8 & 10.4 & 8.7 & 33.1 & 23 & 3.9 & 2.2 & 0.8 & 1.0 & 0.8 & 12.8 \\
\hline $\mathrm{CB} 2$ & 65.3 & 15.3 & 5.3 & 14.1 & 29 & 4.4 & 3.6 & 1.6 & 4.4 & 4.8 & 13.7 \\
\hline CB3 & 27.2 & 23.4 & 1.0 & 48.4 & 16 & 4.1 & 3.7 & 1.8 & 2.7 & 2.6 & 19.1 \\
\hline ITA & 19.3 & 2.2 & 37.5 & 41.0 & 18 & 4,0 & 2.3 & 0.6 & 1.6 & 1.8 & 9.7 \\
\hline SMA & 65.1 & 17.3 & 2.9 & 14.7 & 45 & 4.9 & 46.9 & 5.3 & 48.6 & 13.6 & 1.3 \\
\hline PAR & 36.5 & 5.5 & 43.9 & 14.1 & 15 & 4.1 & 3.6 & 2.0 & 29.0 & 10.3 & 0.9 \\
\hline VOT & 67.0 & 11.1 & 15.3 & 6.6 & 46 & 4.0 & 4.2 & 1.6 & 1.8 & 1.0 & 14.7 \\
\hline
\end{tabular}

${ }^{1}$ Pipette method [28]; ${ }^{2}$ Organic matter determined by potassium dichromate and sulfuric acid extraction;

${ }^{3} \mathrm{CaCl}_{2} 0.01 \mathrm{~mol} \mathrm{~L}{ }^{-1}$ soil to solution ratio 1:2.5; ${ }^{4}$ Ion Exchange resin [29].

\subsection{Growth Assessment}

In all plots, we measured diameter at breast height $(\mathrm{DBH})$, total height and tree survival, and estimated the mean annual increment (MAI) of solid wood volume (SV) with bark. The SV was estimated by allometric equations using DBH and height developed by companies specifically for the genetic material used in each plantation. To compare eucalypt response to $\mathrm{N}$ fertilizer application in all sites, regardless of the growth increment, relative productivity (RP) increase was calculated as follows (Equation (1)).

$$
\mathrm{RP}(\%)=\frac{\mathrm{SV}}{\mathrm{SVmax}} \times 100
$$

where: "SV" is solid wood volume with bark of a given treatment and "SVmax" is the solid wood volume with bark of the highest dose treatment.

\subsection{Soil Analysis}

Soil chemical and physical properties were determined for the 0-20 cm layer at all sites. Ten soil samples were collected from each plot, in a diagonal transect across the inner part of the plot between planting lines. The samples were used to make one mixed sample per plot, which was air dried and homogenized. Next, the samples were sieved through a $2 \mathrm{~mm}$ mesh and mixed up again.

Particle size analysis (pipette method) of soil was performed according to Embrapa [28]. We determined the $\mathrm{pH}$ in $\mathrm{CaCl}_{2} 0.01 \mathrm{~mol} \mathrm{~L}^{-1}$, available phosphorus and exchangeable calcium, magnesium, potassium extracted by ion-exchange resins and aluminum extracted by $\mathrm{KCl} 1 \mathrm{M}$, according to Raij et al. [29]. We assessed soil total carbon $\left(\mathrm{C}_{\mathrm{t}}\right)$ at all sites in the control treatment $(0-20 \mathrm{~cm}$ layer $)$ using the South Dakota method with modifications by Raij et al. [29]. This method consists of organic matter oxidation by dichromate $\left(\mathrm{K}_{2} \mathrm{Cr}_{2} \mathrm{O}_{7}+\mathrm{H}_{2} \mathrm{SO}_{4}\right)$, and quantification by colorimetry. Total $\mathrm{N}\left(\mathrm{N}_{\mathrm{t}}\right)$ was determined by the micro-Kjeldahl method [30]. 


\subsection{Assessment of N Mineralization}

At all sites, soil samples from the $0-20 \mathrm{~cm}$ layer were collected to evaluate potential $\mathrm{N}$ mineralization under anaerobic conditions in the laboratory $\left(\mathrm{N}_{0}\right)$. The samples were collected in April (fall), July (winter), November (spring), 2007, and in January (summer), 2008. We performed anaerobic incubations $\left(40^{\circ} \mathrm{C}\right.$ for 7 days) using chemical methods according to those proposed by Keeney and Bremner [20]. Prior to incubation, $30 \mathrm{~mL}$ of nutritional solution, consisting of: $\mathrm{MgSO}_{4}\left(0.002 \mathrm{~mol} \mathrm{~L}^{-1}\right)$ and $\mathrm{Ca}\left(\mathrm{H}_{2} \mathrm{PO}_{4}\right)_{2}\left(0.005 \mathrm{~mol} \mathrm{~L}^{-1}\right)$, was added. Jars were manually shaken until soil dispersion, and then covered with polyethylene film to avoid water loss by evaporation and algal growth [11]. N was extracted again 7 days after incubation by adding $4.47 \mathrm{~g}$ of $\mathrm{KCl}$ to each jar, which provide a concentration of $2 \mathrm{~mol} \mathrm{~L}^{-1}$ of $\mathrm{KCl}$. Jars were then shaken manually for about $60 \mathrm{~s}$, placed to rest $24 \mathrm{~h}$ and then filtered and analyzed for $\mathrm{NH}_{4}$ as described above. To calculate potentially mineralizable $\mathrm{N}$ we subtracted the initial concentrations of mineral $\mathrm{N}$.

To measure net $\mathrm{N}$ mineralization, the in situ method of Raison et al. [31] was used to in the $0-20 \mathrm{~cm}$ soil layer of control plots. Five pairs of steel tubes $30 \mathrm{~cm}$ long and $5 \mathrm{~cm}$ diameter were placed between tree rows in a diagonal transect across the inner part of the plot. The principle of the method is that inserting a sharpened corer severs roots, and adding capping during in situ incubation excludes rainfall. Net $\mathrm{N}$ mineralization thereby proceeds without leaching or uptake. By measuring mineral N initially (in additional representative soil samples) and again after incubation, net ammonification and nitrification can be calculated. For this study, one tube of each pair was immediately removed to assess initial mineral $\mathrm{N}$ concentrations $\left(\mathrm{t}_{0}\right)$ for all plots, and the remaining tubes were covered to avoid leaching of $\mathrm{N}$, remaining in soil for 30 days on average. The amount of mineral $\mathrm{N}$ at $\mathrm{t}_{0}$ was subtracted from the mineral $\mathrm{N}$ content after incubation to calculate in situ net $\mathrm{N}$ mineralization for each 30 day period. The same rate was assumed for other periods of the same season. Soil from each set of five tubes per plot was mixed to obtain a composite sample. The in situ method was used at all sites for January-December 2008.

For each collection, samples at all sites were collected within 8 days of each other to minimize time-related climatic variations between sites. The tubes were transported vertically to the lab, to minimize disturbance, and they were kept in thermal boxes $\left(2-5{ }^{\circ} \mathrm{C}\right)$, individually wrapped in plastic bags. Refrigeration was used to minimize microbial activity, reducing mineralization that could occur prior to mineral $\mathrm{N}$ extraction [32]. Soil samples remained refrigerated until extraction, which was performed within two days of each collection.

For initial $\mathrm{N}\left(\mathrm{t}_{0}\right)$ extraction, $10 \mathrm{~g}$ of soil were placed in $110 \mathrm{~mL}$ jars and $100 \mathrm{~mL}$ of $\mathrm{KCl} 2 \mathrm{~mol} \mathrm{~L}{ }^{-1}$ added. Jars were manually shaken for c. 60 seconds for soil dispersion, and placed to rest for $24 \mathrm{~h}$. Afterwards, the suspension was filtered through Whatman No. 42 filter paper, and the filtrate was analyzed to for $\mathrm{NH}_{4}{ }^{+}$and $\mathrm{NO}_{3}{ }^{-}$, following the addition of $0.1 \mathrm{~mL}$ of microbial inhibitor (mercury acetate phenyl $0.5 \mathrm{mg} \mathrm{L}^{-1}$ ).

For both $\mathrm{N}_{0}$ and in situ $\mathrm{N}$ mineralization, $\mathrm{NH}_{4}{ }^{+}$and $\mathrm{NO}_{3}{ }^{-}$concentrations were determined using the Analyze System of Injection in Automatic flow-ASIA (Ismatec, Glattbrugg, Switzerland) [33] and detected by colorimetry at $605 \mathrm{~nm}$, which has a detection limit of $0.01 \mu \mathrm{g} \mathrm{mL}^{-1}$. 


\subsection{Data Analysis}

Data were checked for normality (Shapiro-Wilk) and homoscedasticity (Box-Cox). ANOVA was used to assess the significance of differences between means. Where there was a significant $(p<0.05)$ $F$ test, a Tukey test ( $5 \%$ probability) was used for contrasting means. The relationship between dependent and independent variables was assessed by Pearson correlation and linear regression.

\section{Results}

Net $\mathrm{N}$ mineralization in situ rates ranged from 4.8 to $11.5 \mathrm{~kg} \mathrm{ha}^{-1} \mathrm{month}^{-1}$ (fall and winter) and from 10.6 to $15.0 \mathrm{~kg} \mathrm{ha}^{-1}$ month $^{-1}$ (spring and summer) for sandy soils, from 7.4 to $15.2 \mathrm{~kg} \mathrm{ha}^{-1} \mathrm{month}^{-1}$ (fall and winter) and from 11.0 to $17.6 \mathrm{~kg} \mathrm{ha}^{-1} \mathrm{month}^{-1}$ (spring and summer) for loamy soils, and from 3.6 to $19.1 \mathrm{~kg} \mathrm{ha}^{-1}$ month $^{-1}$ (fall and winter) and from 9.4 to $24.3 \mathrm{~kg} \mathrm{ha}^{-1}$ month $^{-1}$ (spring and summer) for clayey soils (Table 3 ). The average rates of $\mathrm{N}$ mineralization were highest in clayey soils, ranging from 110 to $207 \mathrm{~kg} \mathrm{ha}^{-1}$ year $^{-1}$, and the lowest to sandy soils, ranging from 107 to $140 \mathrm{~kg} \mathrm{ha}^{-1} \mathrm{year}^{-1}$. The average ratio of $\mathrm{N}_{-\mathrm{NH}_{4}}{ }^{+} / \mathrm{N}-\mathrm{NO}_{3}$ was 1.6 for sand soils, 1.7 for loamy soils and 1.9 for clayey soils.

Values of $\mathrm{N}_{0}$ during summer ranged from 60 to $154 \mathrm{mg} \mathrm{kg}^{-1}$ of soil (190 and $398 \mathrm{~kg} \mathrm{ha}^{-1}$ ), with an average of $97 \pm 11 \mathrm{mg} \mathrm{kg}^{-1}$ of soil $\left(241 \pm 18 \mathrm{~kg} \mathrm{ha}^{-1}\right)$ (Table 4). Values of $\mathrm{N}_{0}$ in sandy soils during summer were on average $168 \mathrm{~kg} \mathrm{ha}^{-1}$ of $\mathrm{N}_{0}, 212 \mathrm{~kg} \mathrm{ha}^{-1}$ in loamy soils, and $303 \mathrm{~kg} \mathrm{ha}^{-1}$ in clayey soil. During winter, these values ranged from 20 to $91 \mathrm{mg} \mathrm{kg}^{-1}$ of soil (63 and $178 \mathrm{~kg} \mathrm{ha}^{-1}$ ). In sandy soils, $\mathrm{N}_{0}$ corresponded to $19 \%$ of $\mathrm{N}_{\mathrm{t}}, 14 \%$ in loamy soil, and $13 \%$ in clayey soils.

At all sites, tree survival was higher than $95 \%$. On average, nitrogen fertilizer application resulted in an increase in MAI of $14 \%$ at early age, $6 \%$ at intermediate age and $0 \%$ at the end of the crop rotation (Table 5). Relative production (RP) at early age of control treatment ranged from $74 \%$ to $98 \%$ (average of $87 \% \pm 2 \%$ ), and from $90 \%$ to $98 \%$ (average of $95 \% \pm 1 \%$ ) at intermediate age. In the treatment that received commercial fertilizer application, RP ranged from $88 \%$ to $111 \%$ (average of $100 \% \pm 2 \%$ ) at early age, and from $98 \%$ to $107 \%$ (average of $100 \% \pm 1 \%$ ) at intermediate age. After five years of age (approximate harvesting age), RP ranged from 99\% to 103\% (average of $102 \% \pm 1 \%$ ).

The relative wood volume response to $\mathrm{N}$ application was greater in sandy soils, and, in absolute terms, at soils with higher clay content (Table 5 and Figure 2). During the first two years of age, RP of the control was about $16 \%$ lower than in the treatments that received commercial fertilizer application at sandy soils, and $9 \%$ to $10 \%$ at soils with higher clay content. Greater relative response to $\mathrm{N}$ application at early age occurred in soils with lower $\mathrm{N}_{t}, \mathrm{~N}_{0}$ and clay contents (Figure 2). At the end of the rotation, regardless of soil texture, no significant responses to $\mathrm{N}$ application were found.

\section{Discussion}

\section{1. $N$ mineralization}

Higher rates of $\mathrm{N}$ mineralization in clayey soils are attributed to higher stocks of organic $\mathrm{N}$, due to the greater net primary productivity of the ecosystem, and to higher amounts of soil organic-mineral complexes (Tables 3 and 4). Under this condition, microbial activity increases due to higher amounts of substrate [34,35] and water availability. Eaton [36] reported that after two days of intensive rains, clayey 
soils in subtropical forests showed a significant increase in microbial $\mathrm{C}$ and $\mathrm{N}_{-}-\mathrm{NH}_{4}{ }^{+}$mineralization rates, compared to sandier soils. The author speculated that part of the active organic matter pool became detached from soil clay particles, and thereby became available to microorganisms.

Low rates of nitrification (Table 3 ) might be caused by high acidity and low fertility in these soils, and high $\mathrm{NH}_{4}^{+}$uptake under high growth rate stands could restrict substrate availability for nitrifying bacteria [3,37-39]. Under high acidity and low soil fertility, nitrifying bacteria (Nitrobacter and Nitrosomonas) have impaired active. Higher $\mathrm{NH}_{4}{ }^{+}$than $\mathrm{NO}_{3}{ }^{-}$availability is usually not a limitation for eucalypt nutrition [40,41]. Gonçalves and Carlyle [39] studying N mineralization in Pinus radiata plantation soils under laboratory conditions reported that, despite the increased rate of nitrification during incubation, it was not proportional to the reduction of $\mathrm{NH}_{4}{ }^{+}$concentration, showing the possibility of $\mathrm{NH}_{4}{ }^{+}$immobilization and/or denitrification caused by soil moisture variations.
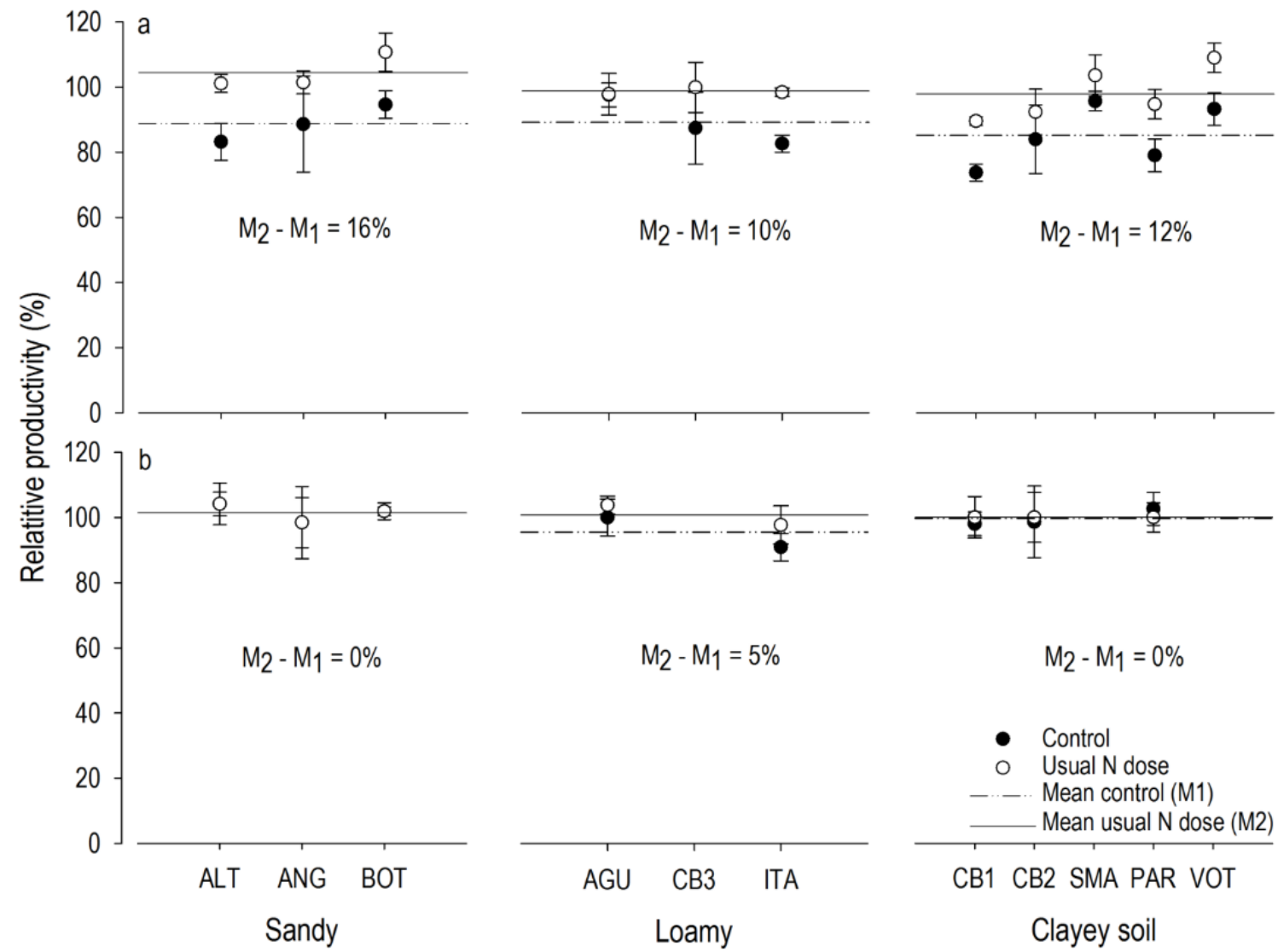

Figure 2. Relative productivity (RP) of the control treatments in relation to the usual and increased $\mathrm{N}$ rate treatments. (a) at young ages (less than two years) and (b) later ages (more than five years) at all sites, grouped according to soil texture. See Table 1 for $x$-axis site codes. 
Table 3. Rates of net ammonification and net nitrification in situ and $\mathrm{N}-\mathrm{NH}_{4}{ }^{+} / \mathrm{N}_{-}-\mathrm{NO}_{3}{ }^{-}$ratio at each site $(0-20 \mathrm{~cm}$ layer).

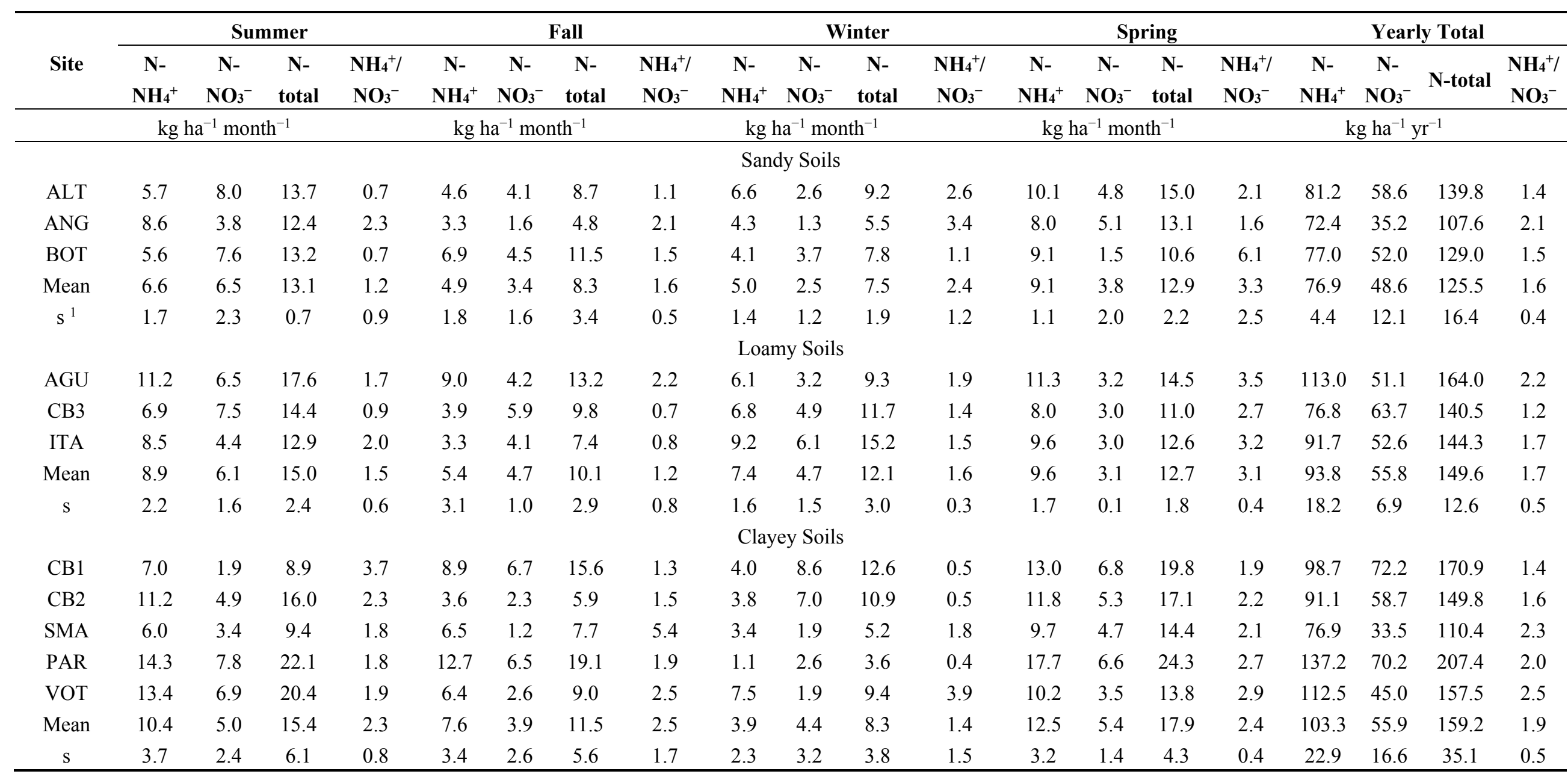

${ }^{1}$ Mean standard deviation. 
Table 4. Seasonal values of potentially mineralizable $N\left(N_{0}\right)$, total $C\left(C_{t}\right)$, total $N\left(N_{t}\right), C / N$ ratio and $\mathrm{N}_{0} / \mathrm{N}_{\mathrm{t}}$ ratio at each site grouped by texture class.

\begin{tabular}{|c|c|c|c|c|c|c|c|c|c|c|c|c|c|}
\hline \multirow{2}{*}{ Site $^{1}$} & \multicolumn{8}{|c|}{$\mathbf{N}_{\mathbf{0}}$} & \multirow{2}{*}{$\mathrm{C}_{\mathrm{t}^{2}}{ }^{2}$} & \multirow{2}{*}{$\mathbf{N}_{t^{3}}$} & \multirow{2}{*}{$\mathbf{N}_{0}{ }^{4}$} & \multirow{2}{*}{$\mathbf{N}_{\mathbf{0}} / \mathbf{N}_{\mathrm{t}}$} & \multirow{2}{*}{$\mathbf{C} / \mathbf{N}$} \\
\hline & Fall & Winter & Spring & Summer & Fall & Winter & Spring & Summer & & & & & \\
\hline & \multicolumn{4}{|c|}{$\mathrm{mg} \mathrm{kg}^{-1}$} & \multicolumn{4}{|c|}{$\operatorname{kg~ha}^{-1}$} & \multicolumn{3}{|c|}{$\mathrm{mg} \mathrm{kg}^{-1}$} & \multicolumn{2}{|c|}{$\%$} \\
\hline \multicolumn{14}{|c|}{ Sandy Soils } \\
\hline ALT & 26 & 20 & 47 & 60 & 82 & 63 & 149 & 190 & 7723 & 387 & 60 & 15 & 20 \\
\hline ANG & 28 & 46 & 39 & 61 & 63 & 103 & 88 & 137 & 7025 & 323 & 61 & 19 & 22 \\
\hline BOT & 53 & 31 & 56 & 66 & 142 & 83 & 150 & 177 & 7090 & 301 & 66 & 22 & 24 \\
\hline Mean & 36 & 32 & 47 & 62 & 96 & 83 & 129 & 168 & 7279 & 337 & 62 & 19 & 22 \\
\hline $\mathrm{s}^{5}$ & 15.0 & 13.1 & 8.5 & 3.2 & 41.2 & 20.0 & 35.5 & 27.6 & 385.6 & 44.7 & 3.2 & 3.5 & 2.0 \\
\hline \multicolumn{14}{|c|}{ Loamy Soils } \\
\hline $\mathrm{AGU}$ & 30 & 42 & 73 & 60 & 84 & 118 & 205 & 169 & 9233 & 387 & 60 & 16 & 24 \\
\hline CB3 & 104 & $-{ }^{6}$ & 95 & 115 & 279 & - & 255 & 309 & 9342 & 810 & 115 & 14 & 12 \\
\hline ITA & 71 & 43 & 73 & 75 & 149 & 90 & 153 & 158 & 7850 & 589 & 75 & 13 & 13 \\
\hline Mean & 68 & 43 & 80 & 83 & 171 & 104 & 205 & 212 & 8808 & 595 & 83 & 14 & 16 \\
\hline $\mathrm{s}$ & 37.1 & 0.7 & 12.7 & 28.4 & 99.3 & 19.8 & 51.0 & 84.2 & 831.7 & 211.6 & 28.4 & 1.5 & 6.7 \\
\hline \multicolumn{14}{|c|}{ Clayey Soils } \\
\hline CB1 & 56 & 69 & 91 & 111 & 139 & 171 & 226 & 275 & 13,403 & 774 & 111 & 14 & 17 \\
\hline $\mathrm{CB} 2$ & 114 & - & 112 & 107 & 276 & - & 271 & 259 & 18,814 & 981 & 107 & 11 & 19 \\
\hline SMA & 34 & 91 & 98 & 125 & 67 & 178 & 192 & 245 & 24,498 & 1267 & 125 & 10 & 19 \\
\hline PAR & 125 & 83 & 108 & 138 & 361 & 240 & 312 & 398 & 10,837 & 893 & 138 & 15 & 12 \\
\hline VOT & 158 & - & 134 & 154 & 344 & - & 292 & 336 & 29,724 & 1276 & 154 & 12 & 23 \\
\hline Mean & 97 & 81 & 109 & 127 & 237 & 196 & 258 & 303 & 19,455 & 1038 & 127 & 13 & 18 \\
\hline $\mathrm{s}$ & 51.1 & 11.1 & 16.4 & 19.4 & 129.3 & 38.0 & 49.0 & 63.6 & 7781.3 & 225.3 & 19.4 & 2.1 & 4.0 \\
\hline
\end{tabular}

${ }^{1}$ Described in Table $1 ;{ }^{2}$ Determined by humid oxidation; ${ }^{3}$ Bremmer [30] method; ${ }^{4}$ adaptation of Keeney and Bremner [20] method; ${ }^{5}$ Mean standard deviation; ${ }^{6}$ Data not collected.

Gonçalves et al. [11] found similar values of $\mathrm{N}_{0}$ in eucalypt stands ranging from 50 to $249 \mathrm{mg} \mathrm{kg}^{-1}$ of soil (average of $111 \pm 23 \mathrm{mg} \mathrm{kg}^{-1}$ of soil). Variations in $\mathrm{N}$ mineralization rates under laboratory conditions due to season of sampling were also found by Adams and Attiwill [42], Khanna [43], Smethurst and Nambiar [38], and Theodorou and Bowen [44]. Those authors also found higher N mineralization rates during temperate summers coinciding with warm, moist soils. For Theodorou and Bowen [44,45], seasonal fluctuations in mineral $\mathrm{N}$ availability were related to microbial activities in the soil, which are mostly affected by temperature and soil moisture [39]. When incubating a soil sample collected during summer, a higher microbial population is also incubated, leading to a higher mineralization rate.

$\mathrm{N}_{0}$ contents were highly correlated with $\mathrm{N}_{\mathrm{t}}(\mathrm{r}=0.92 ; p<0.0001)$, but less so with SOM $(r=0.69$; $p=0,0192)$ and clay contents $(r=0.83 ; p=0,0015)$ (Figure 3$)$. This confirms that soil total $\mathrm{N}$ is a good indicator of potential $\mathrm{N}$ mineralization, as also found by Pottker and Tedesco [46] and Noble and Herbert [47]. However, $\mathrm{N}_{0}$ was only weakly correlated with annual $\mathrm{N}$ mineralization in situ $(r=0.35)$, and the latter was not correlated with $\mathrm{N}_{\mathrm{t}}, \mathrm{SOM}$, or clay content.

The $\mathrm{N}_{0} / \mathrm{N}_{t}$ percentage varied mostly between 10 and 22\% (Table 4), signifying the proportional amount of mineralizable organic N. Gonçalves et al. [11] found $\mathrm{N}_{0} / \mathrm{N}_{\mathrm{t}}$ percentages between $5 \%$ and $15 \%$. 
The $\mathrm{N}_{\mathrm{t}}$ in this study accounted for $3 \%-5 \%$ of SOM. That ratio decreased with increased clay content (Figure 4). Therefore, there may be greater proportional $\mathrm{N}$ availability in soils with lower clay content. High $\mathrm{N}$ mineralization in sandy soils is related to better soil aeration and less clay protection of SOM. In absolute terms though, soils with higher clay content have more potential availability of $\mathrm{N}$, because $\mathrm{N}_{\mathrm{t}}$ stocks are higher.

Table 5. Solid wood volume with bark (SV) and mean annual increment (MAI) in the different treatments and ages at each site.

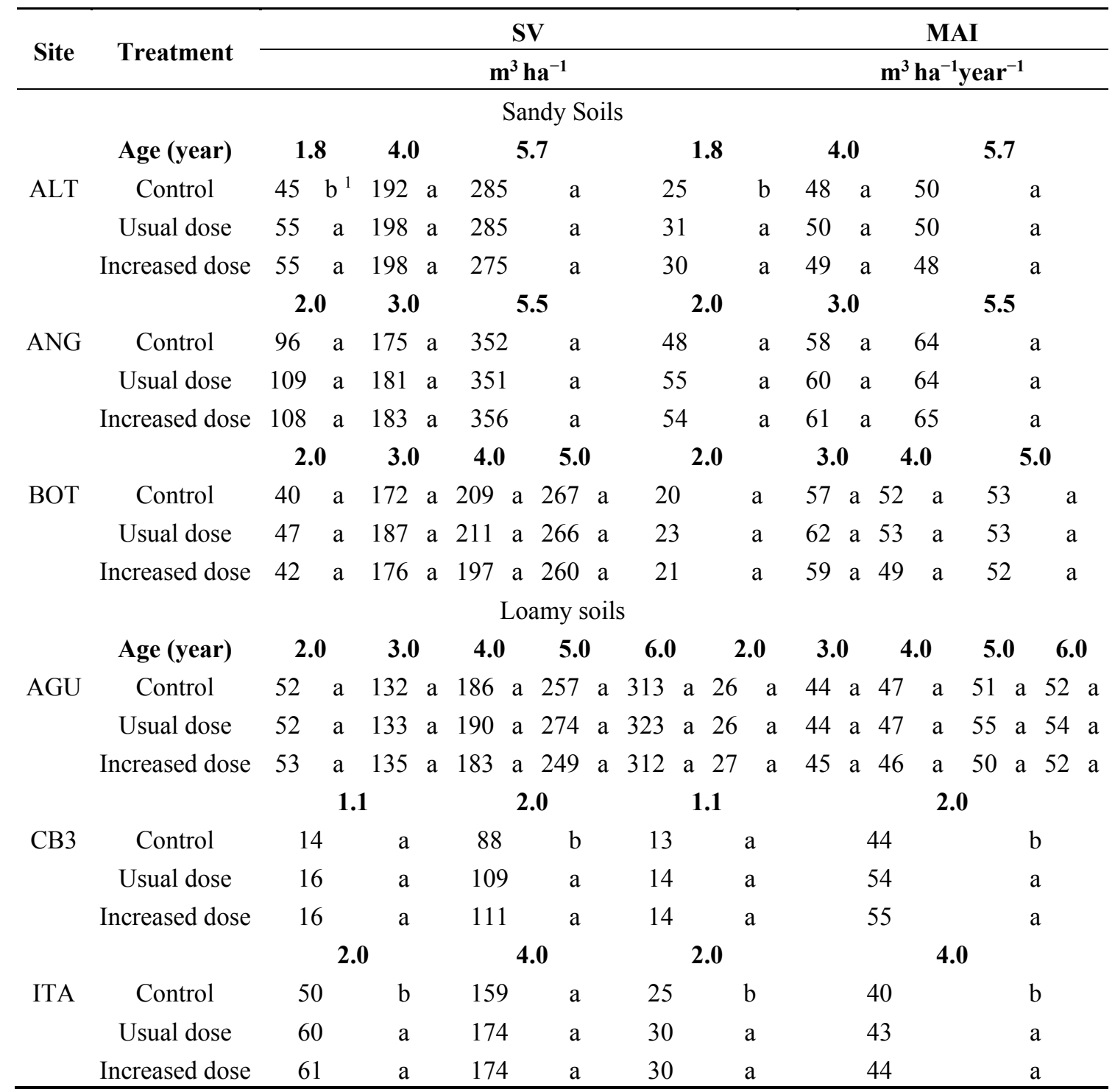


Table 5. Cont.

\begin{tabular}{|c|c|c|c|c|c|c|c|c|c|c|c|c|c|}
\hline \multirow{2}{*}{ Site } & \multirow{2}{*}{ Treatment } & \multicolumn{8}{|c|}{ SV } & \multicolumn{4}{|c|}{ MAI } \\
\hline & & \multicolumn{8}{|c|}{$\mathrm{m}^{3} \mathrm{ha}^{-1}$} & \multicolumn{4}{|c|}{$m^{3}$ ha $^{-1}$ year $^{-1}$} \\
\hline \multicolumn{14}{|c|}{ Clayey Soils } \\
\hline & Age (year) & \multicolumn{2}{|c|}{2.0} & & & \multicolumn{2}{|c|}{9.0} & \multicolumn{2}{|c|}{2.0} & \multicolumn{4}{|c|}{9.0} \\
\hline \multirow[t]{4}{*}{$\mathrm{CB} 1$} & Control & 28 & $\mathrm{~b}$ & 168 & $\mathrm{~b}$ & 452 & $\mathrm{a}$ & 14 & $\mathrm{~b}$ & 42 & $\mathrm{~b}$ & 50 & $\mathrm{a}$ \\
\hline & Usual dose & 33 & $\mathrm{ab}$ & 184 & $\mathrm{ab}$ & 460 & $\mathrm{a}$ & 17 & $\mathrm{ab}$ & 46 & $\mathrm{a}$ & 51 & $\mathrm{a}$ \\
\hline & Increased dose & 38 & $\mathrm{a}$ & 187 & $\mathrm{a}$ & 455 & $\mathrm{a}$ & 19 & $\mathrm{a}$ & 47 & $\mathrm{a}$ & 51 & $\mathrm{a}$ \\
\hline & & \multicolumn{2}{|c|}{1.0} & \multicolumn{2}{|c|}{2.0} & \multicolumn{2}{|c|}{4.7} & \multicolumn{2}{|c|}{1.0} & \multicolumn{2}{|c|}{2.0} & \multicolumn{2}{|c|}{4.7} \\
\hline \multirow[t]{4}{*}{$\mathrm{CB} 2$} & Control & 10 & $\mathrm{a}$ & 80 & $\mathrm{~b}$ & 330 & $\mathrm{a}$ & 10 & $\mathrm{a}$ & 40 & $\mathrm{~b}$ & 70 & $\mathrm{a}$ \\
\hline & Usual dose & 11 & $\mathrm{a}$ & 92 & $\mathrm{a}$ & 332 & $\mathrm{a}$ & 11 & $\mathrm{a}$ & 46 & $\mathrm{a}$ & 71 & $\mathrm{a}$ \\
\hline & Increased dose & 12 & $\mathrm{a}$ & 96 & $\mathrm{a}$ & 333 & $\mathrm{a}$ & 12 & $\mathrm{a}$ & 48 & $\mathrm{a}$ & 71 & $\mathrm{a}$ \\
\hline & & \multicolumn{2}{|c|}{1.5} & \multicolumn{4}{|c|}{2.5} & \multicolumn{2}{|c|}{1.5} & \multicolumn{4}{|c|}{2.5} \\
\hline \multirow[t]{4}{*}{ SMA } & Control & 68 & $\mathrm{a}$ & 1 & & $a$ & & 45 & $\mathrm{a}$ & 75 & & & \\
\hline & Usual dose & 73 & a & 18 & & a & & 49 & $\mathrm{a}$ & 74 & & & \\
\hline & Increased dose & 71 & a & & & a & & 47 & $\mathrm{a}$ & 80 & & & \\
\hline & & \multicolumn{2}{|c|}{2.2} & \multicolumn{2}{|c|}{4.0} & \multicolumn{2}{|c|}{11.4} & \multicolumn{2}{|c|}{2.2} & \multicolumn{2}{|c|}{4.0} & \multicolumn{2}{|c|}{11.4} \\
\hline \multirow[t]{4}{*}{ PAR } & Control & 33 & $\mathrm{a}$ & 146 & $\mathrm{a}$ & 439 & $\mathrm{a}$ & 15 & $\mathrm{a}$ & 36 & $\mathrm{a}$ & 39 & $\mathrm{a}$ \\
\hline & Usual dose & 39 & $\mathrm{a}$ & 153 & $\mathrm{a}$ & 430 & $\mathrm{a}$ & 18 & $\mathrm{a}$ & 38 & $\mathrm{a}$ & 38 & $\mathrm{a}$ \\
\hline & Increased dose & 42 & a & 153 & $\mathrm{a}$ & 430 & $\mathrm{a}$ & 19 & $\mathrm{a}$ & 38 & $\mathrm{a}$ & 38 & $\mathrm{a}$ \\
\hline & & & & & & & & & & & & & \\
\hline VOT & Control & 21 & $\mathrm{~b}$ & 1 & & a & & 18 & $\mathrm{a}$ & 57 & & & \\
\hline & Usual dose & 25 & $\mathrm{a}$ & 1 & & a & & 21 & $\mathrm{a}$ & 62 & & & \\
\hline & Increased dose & 23 & $\mathrm{~b}$ & 18 & & $a$ & & 19 & $\mathrm{a}$ & 59 & & & \\
\hline
\end{tabular}

${ }^{1}$ Values in the same column and site followed by the same letter do not differ statistically by Tukey mean test $(p=0.05)$.

The $\mathrm{C} / \mathrm{N}$ ratio ranged from 12 to 24 (average of $19 \pm 4$ ) (Table 4). Maquere et al. [48], Montero [49] and Lima et al. [50] found higher ratios in eucalypt stands compared to other native vegetation. This explains in part the larger recalcitrance of SOM in eucalypt stands. N release slows as $\mathrm{N}$ mineralization proceeds, since reserves of labile $\mathrm{N}$ decrease along with microbial activity. This effect is unfavorable to plant nutrition in the short-term, but beneficial for $\mathrm{N}$ conservation in the long-term because it decreases $\mathrm{N}$ losses by leaching and volatilization $[37,51,52]$. The $\mathrm{C} / \mathrm{N}$ ratio across sites was inversely correlated with $\mathrm{N}_{0}(\mathrm{r}=0.66, p=0.036)$, confirming that the more recalcitrant SOM has lower potential $\mathrm{N}$ availability. Although not quantified in the current study, temporal changes in $\mathrm{C} / \mathrm{N}$ ratios at each site can be expected [53], whereby these ratios decrease during the early age of a rotation along with specific rates of mineralization (i.e., rates of $\mathrm{N}$ mineralization per unit of carbon). In sandy surface soils ( $0-15 \mathrm{~cm}$ depth) supporting Pinus radiata stands in southeast Australia, the specific rates of $\mathrm{N}$ mineralization decreased by more than $50 \%$ (from 207 to $93 \mathrm{~g} \mathrm{~N} \mathrm{month}^{-1} \mathrm{t}^{-1} \mathrm{C}$ ) during the first four years after planting as $\mathrm{C} / \mathrm{N}$ ratios also decreased in both the $<2 \mathrm{~mm}$ and $>2 \mathrm{~mm}$ soil fractions [53]. For unsieved soil, the $\mathrm{C} / \mathrm{N}$ ratio decreased from 38 to 31 during this period. This slow down in specific rate of $\mathrm{N}$ mineralization might reflect a decrease in the labile pool of organic $\mathrm{N}$ and organic matter quality. Such changes can be expected in any stand prior to replenishment of this labile pool as organic matter and nutrient cycling is restored by above- and below-ground litter production later in the crop rotation. Hence, the relationship 
$\mathrm{C} / \mathrm{N}$ ratio and $\mathrm{N}$ mineralization depends on poorly understood temporal and spatial factors of SOM quality.
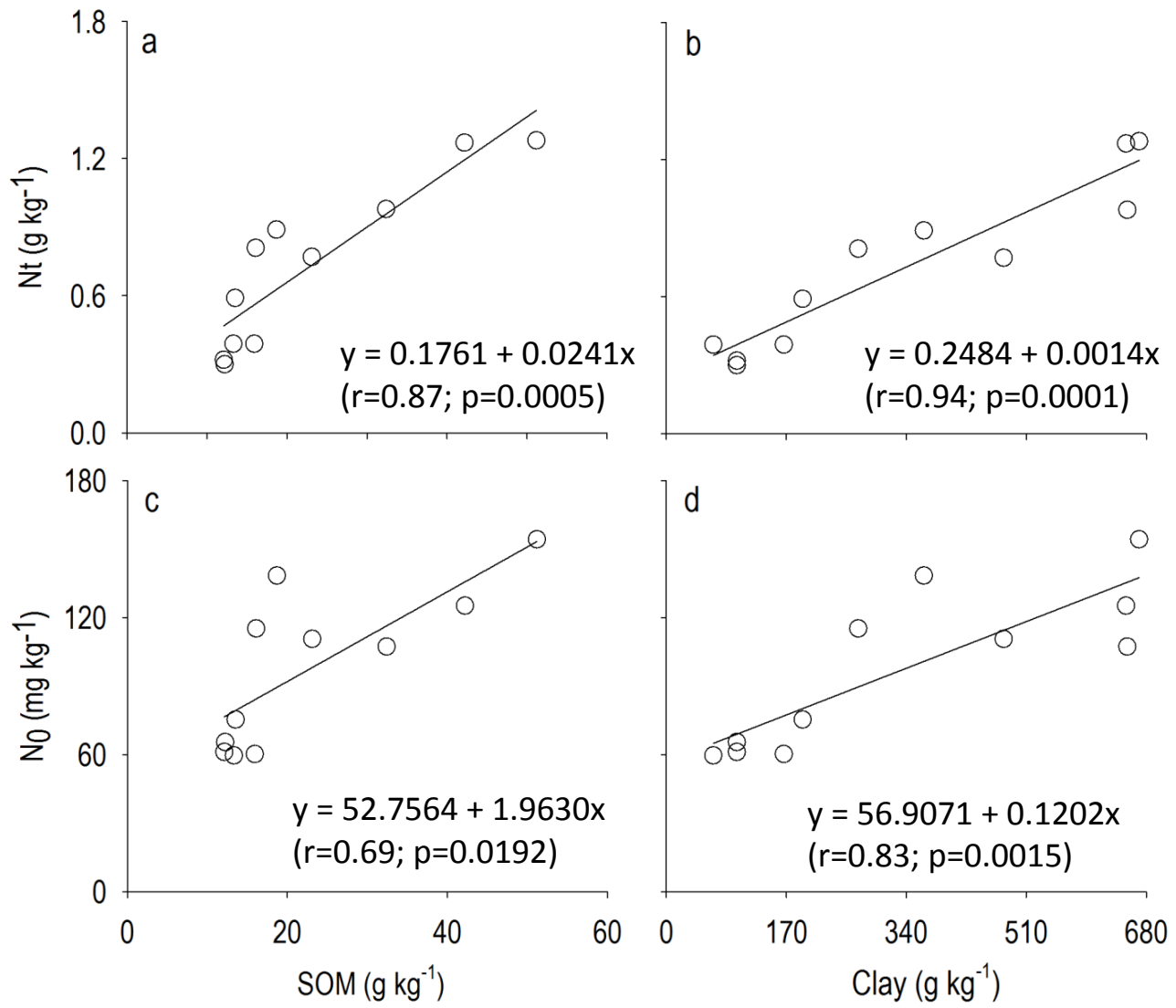

Figure 3. Correlations between soil organic matter (SOM), clay content, total $N\left(N_{t}\right)$ and potentially mineralizable $\mathrm{N}\left(\mathrm{N}_{0}\right)$.

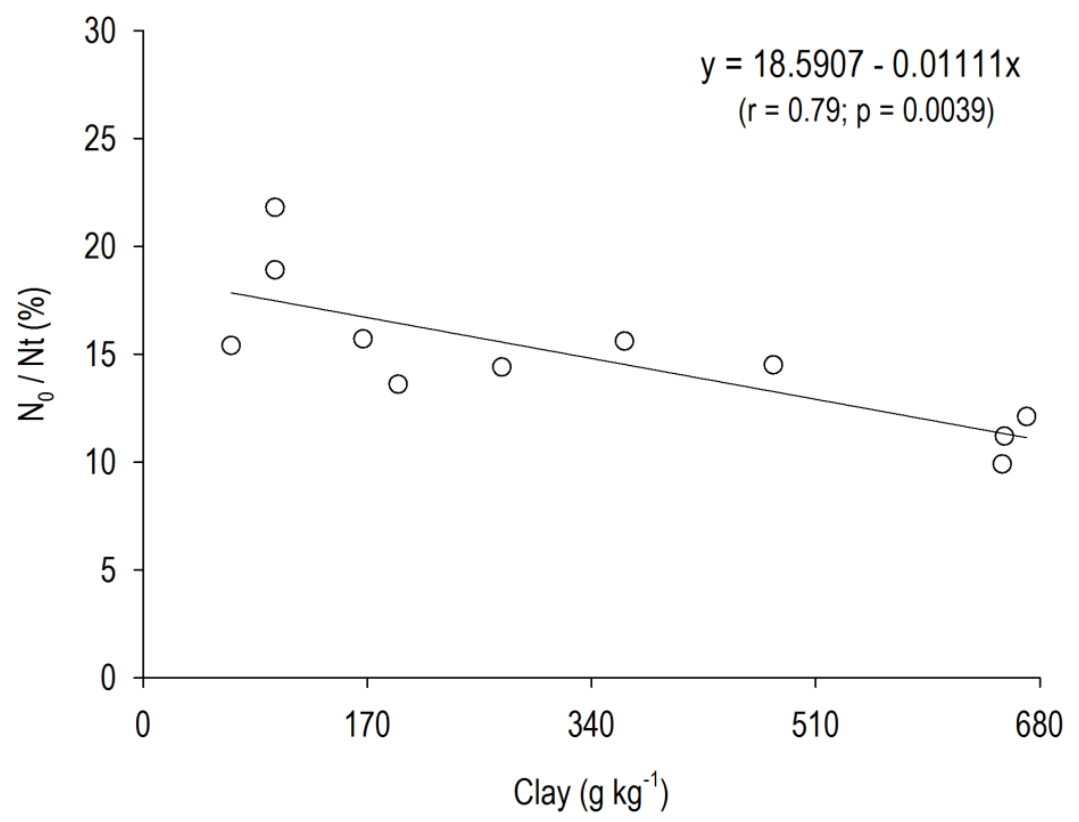

Figure 4. Correlation between clay content and $\mathrm{N}_{0} / \mathrm{N}_{\mathrm{t}}$ ratio across all sites. 


\subsection{Nitrogen Fertilizer Application Response}

The response to $\mathrm{N}$ fertilizer application only occurred at an early stage of tree growth, when the canopy was in formation. For eucalypt stands in Brazil, around $70 \%-80 \%$ of $\mathrm{N}$ accumulates in aboveground components during the first two or three years of growth [1,54]. At this stage, $\mathrm{N}$ relative buildup is higher than biomass accumulation, due to formation of N-rich components (mainly, leaf and fine root), and $\mathrm{N}$ released from SOM by mineralization might not be enough to meet the $\mathrm{N}$ demand of trees [2]. After three years of age, competition among trees for water and light intensifies [55] and tree growth rates decline, leading to reduced $\mathrm{N}$ demand that is mostly supplied by $\mathrm{N}$ released through litter decomposition (biogeochemical cycling) and internal transfers (biochemical cycling) [1,54]. Gonçalves et al. [3] found a biochemical cycling of $54 \mathrm{~kg} \mathrm{~N} \mathrm{ha}^{-1}$ year $^{-1}$ and biogeochemical cycling $42 \mathrm{~kg} \mathrm{~N} \mathrm{ha}^{-1}$ year $^{-1}$ in E. grandis stands at seven years old, which are higher than the amounts required by trees $\left(50 \mathrm{~kg} \mathrm{~N} \mathrm{ha}^{-1}\right.$ year $\left.^{-1}\right)$. Therefore, during early growth, $\mathrm{N}$ fertilizer application may accelerate tree growth rates by increasing $\mathrm{N}$ availability when $\mathrm{N}$ mineralization rates in soil and litter do not supply enough $\mathrm{N}$ to highly demanding trees. However, these responses disappear in subsequent years under the conditions examined here.

The mineral fertilizer requirements of any plantation depend on the nutrient demand required to reach an expected productivity, and the ability of the soil to supply this demand. When plant demand is greater than soil supply, fertilizers must be added. Thus, the criteria for $\mathrm{N}$ fertilizer application should involve only situations where response to $\mathrm{N}$ fertilizer exists, because fertilizer application aims to fill the deficit of $\mathrm{N}$ not released by soils. Fertilizer application practices must be linked with conservative methods of management to minimize $\mathrm{N}$ losses from the system, and thereby increasing sustainability [3].

\section{Acknowledgments}

The authors wish to thank Duratex S.A., Fibria Celulose S.A., International Paper of Brazil and Suzano Papel e Celulose S.A. for the financial support and making their areas available for the project. We also thank the Silviculture and Management Thematic Program (PTSM) of IPEF for financial support and assistance with for fieldwork. We also thank Antonio Bianchi for the revision of the English.

\section{Author Contributions}

Ana Paula Pulito, José Leonardo de Moraes Gonçalves, Luiz Fabiano de Moraes, José Luiz Gava, Raul Chaves and Claudio Roberto Silva designed the study and conducted of field trial. Ana Paula Pulito, José Carlos Arthur Junior, Aline Cristina Miranda and Marcos Yassuo Kamogawa were responsible for the samples collection and laboratory analysis. Ana Paula Pulito, José Carlos Arthur Junior, Clayton Alcarde Alvares and José Henrique Tertulino Rocha, were responsible for the statistical analyses, with contribution from José Leonardo de Moraes Gonçalves. Ana Paula Pulito, José Leonardo de Moraes Gonçalves, Philip J. Smethurst, Clayton Alcarde Alvares, José Henrique Tertulino Rocha and Ayeska Hübner wrote the paper. 


\section{Conflicts of Interest}

The authors declare no conflict of interest.

\section{References}

1. Barros, N.F.; Novais, R.F.; Neves, J.C.L. Fertilização e correção do solo para o plantio de eucalipto. In Relação Solo- Eucalipto; Barros, N.F., Novais, R.F., Eds.; UFV: Viçosa, MG, Brazil, 1990; Volume 4, pp. 127-186.

2. Gonçalves, J.L.M.; Alvares, C.A.; Higa, A.R.; Silva, L.D.; Alfenas, A.C.; Stahl, J.; Ferraz, S.F.B.; Lima, W.P.; Brancalion, P.H.S.; Hubner, A.; et al. Integrating genetic and silvicultural strategies to minimize abiotic and biotic constraints in Brazilian eucalypt plantations. For. Ecol. Manag. 2013, $301,6-27$.

3. Gonçalves, J.L.M.; Stape, J.L.; Laclau, J.P.; Bouillet, J.P.; Ranger, J. Assessing the effects of early silvicultural management on long-term site productivity of fast growing Eucalypt plantations: The Brazilian experience. South. For. 2008, 70, 105-118.

4. Gonçalves, J.L.M.; Barros, N.F.; Nambiar, E.K.S.; Novais, R.F. Soil and stand management for short-rotation plantations. In Management of Soil, Nutrients and Water in Tropical Plantation Forests; Nambiar, S., Brown, A., Eds.; ACIAR Austrália/CSIRO Austrália/CIFOR Indonésia: Canberra, Australia, 1997; pp. 379-418.

5. Herbert, M.A.; Schönau, A.P.G. Fertilizing commercial forest species in southern Africa: Research progress and problems (part 1). S. Afr. For. J. 1989, 151, 58-70.

6. Reis, M.G.F.; Barros, N.F.; Kimmins, J.P. Acúmulo de nutrientes em uma sequência de idade de Eucalyptus grandis (ex-Maiden) plantado no cerrado, em duas áreas com diferentes produtividades, em Minas Gerais. Rev. Árvore 1987, 11, 1-15.

7. Laclau, J.-P.; Ranger, J.; Goncalves, J.L.M.; Maquere, V.; Krusche, A.V.; M'Bou, A.T.; Nouvellon, Y.; Saint-Andre, L.; Bouillet, J.-P.; Piccolo, M.D.C.; et al. Biogeochemical cycles of nutrients in tropical Eucalyptus plantations Main features shown by intensive monitoring in Congo and Brazil. For. Ecol. Manag. 2010, 259, 1771-1785.

8. Dovey, S.B.; du Toit, B.; Clercq, W. Nutrient fluxes in Rainfall, Throughfall and Stemflow in Eucalyptus Stands on the Zululand Coastal Plain, South Africa. South. For. 2011, 73, 193-206.

9. Sato, A.M.; Souza, A.A.; Coelho Netto, A.L. Spatial variability and temporal stability of throughfall in a eucalyptus plantation in the hilly lowlands of southeastern Brazil. Hydrol. Process. 2011, 25, 1910-1923.

10. Mayer, R.; Liess, S.; Lopes, M.I.M.S.; Kreutzer, K. Atmospheric pollution in a tropical rain forest: effects of deposition upon biosphere and hydrosphere II. Fluxes of chemicals and element budgets. Water Air Soil Pollut. 2000, 121, 79-92.

11. Gonçalves, J.L.M.; Mendes, K.C.F.S.; Sasaki, C.M. Mineralização de nitrogênio em ecossistemas florestais naturais e implantados do estado de São Paulo. Rev. Bras. Cienc Solo 2001, 25, 601-616. 
12. Poggiani, F. Ciclagem de nutrientes em ecossistemas de plantações florestais de Eucalyptus e Pinus: Implicações silviculturais. Tese (Livre Docência)_Escola Superior de Agricultura "Luiz de Queiroz"; Universidade de São Paulo: Piracicaba, Brazil, 1985.

13. Godinho, V.P.C.; Barros, N.F.; Pereira, P.R.G.; Sediyama, C.S.; Fluxo parcial de nitrogênio e potássio em solo arenoso de cerrado, sob povoamentos de Eucalyptus camaldulensis, influenciado pelo modo de aplicação de adubo nitrogenado e potássico. In Proceedings of the IUFRO Conference on silviculture and improvement of eucalyptus, Salvador, Brazil, 12-15 November 1997; pp. 125-133.

14. Smethurst, P.; Baillie, C.; Cherry, M.; Holz, G. Fertilizer effects on LAI and growth of four Eucalyptus nitens plantations. For. Ecol. Manag. 2003, 176, 531-542.

15. Laclau, J.P.; Ranger, J.; Deleporte, P.; Nouvellon, Y.; Saint-André, L.; Marlet, S.; Bouillet, J.P. Nutrient cycling in a clonal stand of Eucalyptus and an adjacent savanna ecosystem in Congo. 3. Input-output budgets and consequences for the sustainability of the plantations. For. Ecol. Manag. 2005, 210, 375-391.

16. Cantarella, H.; Van Raij, B. Adubação nitrogenada no Estado de São Paulo. In Reunião brasileira de fertilidade do solo; SBCS: Ilhéus, Brazil, 1986; pp. 47-79.

17. Larcher, W. Ecofisiologia vegetal; Rima: São Carlos, Brazil, 2004; p. 531.

18. Gianello, C.; Bremner, J.M. A simple chemical method of assessing potentially available organic nitrogen in soil. Commun. Soil Sci. Plant Anal. 1986, 17, 195-214.

19. Hopmans, P.; Flinn, D.W.; Farrel, P.W. Nitrogen mineralization in a sandy soil under native Eucalypt forest and exotic Pine plantations in relation to moisture content. Commun. Soil Sci. Plant Anal. 1980, 1, 71-79.

20. Keeney, D.R.; Bremner, J.M. Comparison and evaluation of laboratory methods of obtaining an index of soil nitrogen availability. Agron. J. 1966, 58, 498-503.

21. Corbeels, M.; Mc Murtrie, R.E.; Pepper, D.A.; Mendham, D.S.; Grove, T.S.; O’Connell, A.M. Long-term changes in productivity of eucalypt plantations under different harvest residue and nitrogen management practices: A modelling analysis. For. Ecol. Manag. 2005, 217, 1-18.

22. Alvares, C.A.; Stape, J.L.; Sentelhas, P.C.; Gonçalves, J.L.M.; Sparovek, G. Köppen's climate classification map for Brazil. Meteorologische Zeitschrift 2013, 22, 711-728.

23. Embrapa. Sistema Brasileiro de Classificação de Solos, 3rd ed.; Embrapa: Brasília, Brazil, 2013; p. 353.

24. Gonçalves, J.L.M.; Alvares, C.A.; Gonçalves, T.D.; Moreira, R.M.; Mendes, J.C.T.; Gava, J.L. Mapeamento de solos e da produtividade de plantações de Eucalyptus grandis em Itatinga, SP, com uso de sistema de informação geográfica. Sci. For. 2012, 94, 187-201.

25. Alvares, C.A.; Gonçalves, J.L.M.; Vieira, S.R.; Silva, C.R.; Franciscatte, W. Spatial variability of physical and chemical attributes of some forest soils in southeastern of Brazil. Sci. Agri. 2011, 68, $697-705$.

26. Alvares, C.A.; Stape, J.L.; Sentelhas, P.C.; Gonçalves, J.L.M. Modeling monthly mean air temperature for Brazil. Theor. Appl. Climatol. 2013, 113, 407-427.

27. IPT-Instituto de Pesquisas Tecnológicas do Estado de São Paulo. Mapa geológico do Estado de São Paulo; escale 1:500.000. Secretaria da Indústria, Comércio, Ciência e Tecnologia: São Paulo, Brazil, 1981. 
28. EMBRAPA. Manual de métodos de análise de solo; Embrapa: Rio de Janeiro, Brazil, 1999; p. 212.

29. Van Raij, B.; Andrade, J.C.; Cantarella, H.; Quaggio, J.A. Análise química para avaliação da fertilidade de solos tropicais; Instituto Agronômico: Campinas, Brazil, 2001; p. 285.

30. Bremner, J.M. Organic nitrogen in soils. In Soil Nitrogen; Bartholomew, W.V., Clark, F.E., Eds.; American Society of Agronomy: Madson, WI, USA, 1965; pp. 93-149.

31. Raison, R.J.; Connell, M.J.; Khanna, P.K. Methodology for studying fluxes of soil mineral-N in situ. Soil Biol. Biochem. 1987, 19, 521-530.

32. Arnold, J.; Corre, M.D.; Veldkamp, E. Cold storage and laboratory incubation of intact soil cores do not reflect in-situ nitrogen cycling rates of tropical Forest soils. Soil Biol. Biochem. 2008, 40, 2480-2483.

33. Kamogawa, M.Y.; Teixeira, M.A. Auto-amostrador de baixo custo para análise por injeção em fluxo. Quim. Nova 2009, 32, 1644-1646.

34. Jenkinson, D.S.; Ladd, J.N. Microbial biomass in soil: Measuremente and turnover. In Soil Biochemistry; Paul, E.A., Ladd, J.N., Eds.; Marcel Deker: New York, NY, USA, 1981; pp. 425-471.

35. Van Veen, J.A.; Ladd, J.N.; Martin, J.K.; Amato, M. Turnover of carbon, nitrogen and phosphorus through the microbial biomass in soils incubated with ${ }^{14} \mathrm{C}-,{ }^{15} \mathrm{~N}$ - and ${ }^{32}$-P-labelled bacterial cells. Soil Biol. Biochem. 1987, 19, 559-565.

36. Eaton, W.D. Microbial and nutrient activity in soils from three different subtropical forest habitats in Belize, Central America, before and during the transition from dry to wet season. Appl. Soil Ecol. 2001, 16, 219-227.

37. Carlyle, J.C. Nitrogen cycling in forested ecosystems. For. Abstr. 1986, 47, 307-336.

38. Smethurst, P.J.; Nambiar, E.K. Distribution of carbon and nutrients and fluxes of mineral nitrogen after-clearfelling a Pinus radiata plantation. Can. J. For. Res. 1990, 20, 1490-1497.

39. Gonçalves, J.L.M.; Carlyle, J.C. Modelling the influence of moisture and temperature on net nitrogen mineralization in a forested sandy soil. Soil Biol. Biochem. 1994, 26, 1557-1564.

40. Garnett, T.P.; Shabala, S.N.; Smethurst, P.J.; Newman, I.A. Kinetics of ammonium and nitrate uptake by eucalypt roots and associated proton fluxes measured using ion selective microelectrodes. Funct. Plant Biol. 2003, 30, 1165-1176.

41. Vale, F.R.; Novais, R.F.; Barros, N.F. Efeito do alumínio sobre a cinética de absorção de amônio e nitrato em raízes intactas de Eucalyptus alba. Rev. Árvore 1984, 8, 123-132.

42. Adams, M.A.; Attiwill, P.M. Nutrient cycling and nitrogen mineralization in eucalypt forests of souther-eastern Australia- II. Indices of nitrogen mineralization. Plant Soil 1986, 92, 341-362.

43. Khanna, P.K. Measurement of changes in the nitrogen status of forest soils due to management practices. In Proceedings of the International Symposium on Forest Soils, Harbin, China, 22-27 July 1990; p.10.

44. Theodorou, C.; Bowen, G.D. Nitrogen transformations in first- and second-rotation Pinus radiata forest soil. Austral. For. Res. 1983, 13, 103-112.

45. Theodorou, C.; Bowen, G.D. Effects of temperature, moisture and litter on nitrogen mineralization in Pinus radiata forest soils. Austral. For. Res. 1983, 13, 113-119.

46. Pottker, D.; Tedesco, M.J. Efeito do tipo e tempo de incubação sobre a mineralização da matéria orgânica e nitrogênio total em solos do Rio Grande do Sul. Rev. Bras. Cienc Solo 1979, 3, 20 -24. 
47. Noble, A.D.; Herbert, M.A. Influence of soil organic matter content on the responsiveness of Eucalyptus grandis to nitrogen fertiliser. S. Afr. For. J. 1991, 156, $23-27$.

48. Maquere, V.; Laclau, J.P.; Bernoux, M.; Saint-Andre, L.; Gonçalves, J.L.M.; Cerri, C.C.; Piccolo, M.C.; Ranger, J. Influence of land use (savanna, pasture, Eucalyptus plantations) on soil carbon and nitrogen stocks in Brazil. Eur. J. Soil Sci. 2008, 59, 863-877.

49. Montero, L.L. Carbono em solos de cerrado: efeitos do uso florestal. Tese (Doutorado em Ciências, na área de Ecologia) — Instituto de Biociências, Universidade de São Paulo, São Paulo, Brazil, 2008.

50. Lima, A.M.N.; Silva, I.R.; Neves, J.C.L.; Novais, R.F.; Barros, N.F.; Mendonça, E.D.; Smyth, T.J.; Moreira, M.S.; Leite, F.P. Soil organic carbon dynamics following afforestation of degraded pastures with eucalyptus in southeastern Brazil. For. Ecol. Manag. 2006, 235, 219-231.

51. Vitousek, P.M. Litterfall, nutrient cycling and nutrient limitation in tropical forest. Ecology 1984, 65, 285-298.

52. Attiwill, P.M.; Leeper, G.W. Forest Soils and Nutrient Cycles. Melbourne University: Carlton, Australia, 1987; p. 202.

53. Smethurst, P.J.; Nambiar, E.K.S. Changes in soil carbon and nitrogen during the establishment of a second crop of Pinus radiata. For. Ecol. Manag. 1995, 73, 145-155.

54. Barros, N.F.; Neves, J.C.L.; Novais, R.F. Recomendação de fertilizantes minerais em plantios de eucalipto. In Nutrição e fertilização florestal; Gonçalves, J.L.M., Benedetti, V., Eds.; IPEF: Piracicaba, Brazil, 2000; pp. 269-286.

55. Ryan, M.G.; Stape, J.L.; Binkley, D.; Fonseca, S.; Loos, R.A.; Takahashi, E.N.; Silva, C.R.; Silva, S.R.; Hakamada, R.E.; Ferreira, J.M.; et al. Factors controlling Eucalyptus productivity: How water availability and stand structure alter production and carbon allocation. For. Ecol. Manag. 2010, 259, 1695-1703.

(C) 2015 by the authors; licensee MDPI, Basel, Switzerland. This article is an open access article distributed under the terms and conditions of the Creative Commons Attribution license (http://creativecommons.org/licenses/by/4.0/). 